\title{
Failure of carbaryl-based products to reduce brown dog tick populations in Puerto Rico'
}

\author{
Irving Fox and Delfin de León ${ }^{2}$
}

\begin{abstract}
Powders containing carbaryl, and carbaryl plus pyrethrins applied once per week to a dog were ineffective against the brown dog tick. Ahipicephalus sanguineus Latreille. A collar impregnated with carbaryl was also ineffective. A spray containing carbaryl and pyrethrins did not reduce the number of ticks on another dog nor those in the house, when applied daily to the resting place of the dog.
\end{abstract}

\section{INTRODUCTION}

The brown dog tick, Rhipicephalus sanguineus Latreille, occurs throughout the West Indies (8), and is a pest all over Puerto Rico (6). Although carbaryl has been rated highly as an acaricide by veterinarians and entomologists $(4,5)$, its efficacy against brown dog ticks in Puerto Rico has not been documented. The label of a carbaryl powder tested here reads, "Especially designed for the control of resistant brown dog ticks, fleas, and lice." Nevertheless, we present data in this report which indicate that carbaryl is not effective against brown dog ticks in Puerto Rico.

Heretofore, no report has been published on the efficacy of the carbaryl collar against ticks (3). Miller et al. (7) found that the carbaryl collar was effective against cat fleas on dogs and cats in California. Our previous studies have shown that in Puerto Rico carbaryl powder was not effective against cat fleas (2) nor against cat fur mites (1).

\section{MATERIALS AND METHODS}

Two large dogs were used as experimental animals. One (1) was a male with a black coat, white chest, and white toes, similar to the Bernese Mountain dog, weighing about $25 \mathrm{~kg}$ and about $70 \mathrm{~cm}$ high; he slept on the porch, had free run of the patio and street, but was never allowed indoors. The other $\operatorname{dog}(2)$ was a male Collie weighing about $23 \mathrm{~kg}$, and about $61 \mathrm{~cm}$ high; he slept inside the house and was never allowed off the leash, spending most of the time indoors.

A powder with carbaryl as the only active ingredient, another powder

\footnotetext{
1 Manuscript submitted to Editorial Board March 14, 1986.

${ }^{2}$ Professor, Department of Microbiology and Medical Zoology, School of Medicine, Medical Sciences Canpus, University of Puerto Rico, San Juan, PR 00936; and Veterinarian, Agricultural Experiment Station, Mayagiez Campus, University of Puerto Rico, Rio Piedras, PR 00928. The authors thank Mr. Victor Vélez, Sales Representative, Beecham Laboratories, for supplying most of the acaricides used in the experiment.
} 
with carbaryl plus other active ingredients, and a collar impregnated with carbaryl obtained from a sales representative were used. The spray was purchased from a veterinary supply house. The active ingredients shown on the labels were: Carbaryl powder, 1-naphthyl N-methylcarbamate, $5.00 \%$; carbaryl plus powder, 1-naphthyl N-methylcarbamate, $5.00 \%$, piperonyl butoxide, $1.00 \%$, and pyrethrins, $0.100 \%$; carbaryl collar, 1 naphthyl N-methylcarbamate, $16 \%$; carbaryl spray, 1-naphthyl N-methylcarbamate, $0.500 \%$, pyrethrins, $0.050 \%$, piperonyl butoxide, $0.100 \%$, and $\mathrm{N}$-octyl bicycloheptene dicarboximide, $0.166 \%$.

The dogs suffered heavy infestations of naturally acquired ticks. To make the tests with the powders, about one teaspoon was dusted, mainly over the back and sides, giving a dosage of $220-300 \mathrm{mg} / \mathrm{kg}$. The powder was applied on Saturday of each week, and the female ticks were counted daily and totaled weekly. Every day all the ticks seen on the dog were handpicked and destroyed. This procedure was followed for 5 weeks with

TABIE 1.-Number of female brown dog ticks removed from a dog daily after applying a pouder conlaining $5.00 \%$ carbaryl once per week

\begin{tabular}{crrr}
\hline Week & Total & Average & Range \\
\hline $0^{1}$ & 50 & 7.14 & $3-13$ \\
1 & 48 & 6.86 & $2-10$ \\
2 & 48 & 6.86 & $2-10$ \\
3 & 173 & 24.71 & $13-36$ \\
4 & 79 & 11.28 & $4-18$ \\
5 & 108 & 15.42 & $3-27$ \\
\hline
\end{tabular}

${ }^{1}$ Pretreatment count (before applying acaricide).

carbaryl powder and for 8 weeks with the carbaryl plus powder. The collar was applied and remained continuously on the dog for 5 weeks; the female ticks were counted and removed daily. The spray was applied daily for 7 days on the floor and walls where the dog rested, but not on the dog. Male and female ticks were counted and removed from the dog and house every day. Dog 1 was used for the tests with carbaryl powders and collar, and Dog 2 for the experiments with the spray.

\section{RESULTS AND DISCUSSION}

The results are shown in tables 1 to 4 . Despite treatments with the carbaryl powder (table 1), ticks were always present on the dog. After five applications, there were more than twice as many ticks as before the treatments. The powder containing carbaryl plus pyrethrins (table 2) did cause a temporary reduction in ticks after 5 weeks of treatments. However, when the treatments were continued for 3 more weeks, the ticks 
became abundant, reaching a very high level. Table 3 shows that while the dog was wearing the carbaryl collar he was continuously infested with ticks, and had more ticks after 5 weeks than before wearing the collar. Nor did the carbaryl in a spray eliminate the ticks (table 4).

TABLE 2.-Number of female brown dog licks removed from a dog daily after applying a powder containing carbaryl, $5.00 \%$ piperonyl butoxide, $1.00 \%$, and pyrethrins, $0.100 \%$, once

\begin{tabular}{crrl}
\multicolumn{4}{c}{ per week } \\
\hline Week & 'Total & Average & Range \\
\hline $0^{1}$ & 50 & 7.14 & $3-13$ \\
1 & 35 & 5.00 & $1-7$ \\
2 & 19 & 2.71 & $2-6$ \\
3 & 32 & 4.57 & $0-17$ \\
4 & 9 & 1.29 & $0-3$ \\
5 & 6 & 0.86 & $0-2$ \\
6 & 34 & 4.86 & $0-14$ \\
7 & 378 & 54.00 & $7-169$ \\
8 & 54 & 7.71 & $0-21$ \\
\hline
\end{tabular}

' Pretreatment count (before applying acaricide).

TABLE 3.-Number of female brown dog ticks removed from a dog daily after applying a collar containing $16 \%$ carbaryl

\begin{tabular}{crrl}
\hline Week & Total & Average & Range \\
\hline $0^{1}$ & 48 & 6.86 & $8-15$ \\
1 & 112 & 16.00 & $9-27$ \\
2 & 86 & 12.29 & $4-20$ \\
3 & 24 & 3.43 & $1-6$ \\
4 & 19 & 2.71 & $0-2$ \\
5 & 57 & 8.14 & $3-17$ \\
\hline
\end{tabular}

'Pretreatment count (before applying the collar).

TABLE 4--Number of brown dog tichs removed from a dog and the house after daily treatments of the dog's resting place with a spray containing carbaryl plus other active ingredients

\begin{tabular}{ccrcc}
\hline \multirow{2}{*}{ Day } & \multicolumn{2}{c}{ Dog } & & \multicolumn{2}{c}{ House } \\
\cline { 2 - 3 } \cline { 5 - 5 } & Females & Males & Females & Males \\
\hline 1 & 49 & 80 & 0 & 31 \\
2 & 108 & 109 & 12 & 20 \\
3 & 70 & 34 & 7 & 6 \\
4 & 118 & 38 & 5 & 5 \\
5 & 55 & 46 & 11 & 5 \\
6 & 55 & 44 & 5 & 9 \\
7 & 46 & 79 & 18 & 23 \\
Total & 501 & 430 & 58 & 81 \\
\hline
\end{tabular}


Despite daily treatments of the dog's resting place over a period of 7 days, more than a thousand ticks were removed from the dog and the house. The results of these practical experiments with carbaryl in powders, collar, and spray indicate that the brown dog tick, if it ever was susceptible to carbaryl in Puerto Rico, is now resistant to that acaricide.

\section{RESUMEN}

Los polvos que contenian carbaril y carbaril y piretrinas fueron ineficaces para combatir la garrapata parda del perro cuando se le aplicaron 1 vez a la semana a un perro. Un collar impregnado con carbaril también fue ineficaz. Una aspersión con carbaril y piretrinas no redujo el número de garrapatas en el perro ni en la casa cuando se aplicó diariamente al sitio de descanso del perro.

\section{LITERATURE CITED}

1. Fox, I. and D. de León, 1982. Evaluation of insecticides in collars and powders against the cat fur mite Felistrophorus rodofskyi (Tenorio) on Persian cats, J. Agric. Univ. P. R. 66: 139-44.

2. $\longrightarrow$ and - , 1984. Insecticidal powders containing methoxychlor, rotenone, or carbaryl fail to reduce populations of fleas in a cat in Puerto Rico, J. Agric. Univ, P. R. 68: 311-2.

3. - and - 1985. Efficacy of collars containing dichlorvos, naled or stirofos against fleas on Persian cats in Puerto Rico, J. Agric. Univ. P. R. 69; 421-7.

4. Hourrigen, J. I., K. K. Strickland, O. L. Kelsey, B. E. Knisley, C. C. Crago, S. Whittaker and D. J. Gilhooly, 1969. Eradication efforts against tropical bont tick, Amblyomma variegalum, in the Virgin Islands, J. Am. Vet. Med. Assoc. 154: 540-5.

5. Koch, H. G. and H. E. Burkwhat, 1984, Susceptibility of the brown dog tick (Acari : Ixodidae) to fresh residues of acaricides: Laboratory assays and comparison of susceptibility of different life stages of the lone star and American dog tick, J. Econ. Entomol. 77: 670-4.

6. Maldonado-Capriles, J. and S. Medina-Gaud, 1977. The ticks of Puerto Rico (Arachnida: Acarina), J. Agric. Univ. P. R. 61: 402-4.

7. Miller, J. E., N. F. Baker and E. L. Colhurn, 1977. Insecticidal activity of propoxurand carbaryl-impregnated flea collars against Ctenoccphalides felis, Am. J. Vet. Res. 38: 923-5.

8. Morel, P. C., 1966. Étude sur les tiques du bétail en Guadeloupe et Martinique I. Les tiques et leur distribution (Acariens, Ixodoidea), Rev. Elev. Méd. Vet. Pays Trop. 19: $307-21$. 